\section{JOURNAL}

OF URBAN

SOCIETY'S ARTS

Volume 2 Nomor 2,

Oktober 2015: 80-88

\title{
Eksistensi Gula Gending di dalam Dinamika Budaya Lombok
}

\section{Nyoman Triyanuartha}

Minat Utama Pengkajian Seni Musik Barat,

Magister Penciptaan dan Pengkajian Seni,

Program Pascasarjana Institut Seni Indonesia Yogyakarta

E-mail: tritanuartha@ymail.com; HP: 085643807927

\begin{abstract}
ABSTRAK
Penelitian ini bertujuan untuk mengungkap eksistensi gula gending di dalam dinamika budaya yang terjadi di Lombok. Gula gending merupakan sebuah pertunjukan musik yang dimainkan ketika pedagang harum manis mepromosikan barang dagangannya untuk menarik perhatian calon pembeli. Seiring dengan perjalanan waktu, pertunjukan musik ini menjadi langka dan jarang ditemukan di dalam masyarakat. Kini gula gending muncul kembali dengan beberapa perkembangan yang menyertainya. Analisis dilakukan terhadap fakta musikal yang meliputi dimensi sonorik, dimensi visual dan dimensi kinestetik. Untuk membahas mengenai penyebab dan hasil dari perkembangan akan digunakan konsep music and cutural dynamic.
\end{abstract}

Kata kunci: Gula Gending, eksistensi, dinamika budaya, Lombok

\begin{abstract}
The Existence of Gula Gending in Lombok's Cultutral Dynamic. This research aims to gasp the exsistence of gula gending in cultural dynamic which occurs in Lombok. Gula gending was a music performance played when the arbanat seller was promoting their goods to attract the customers' attention. As the time goes by, this music performance becomes rare, so we seldom find its existence in society. In spite of the fact, nowdays gula gending reappears along with few following developments. An analysis has been done to the musical facts which may include among athers are sonoric dimention, visual dimention, and kinesthetic dimention. To gain the explanation about the causes and results of the development, music and cultural dynamic concepts are conducted.
\end{abstract}

Keywords: Gula Gending, existence, cultural dynamic, Lombok

\section{Pendahuluan}

Identitas Pulau Lombok sebagai tempat berdiamnya suku Sasak antara lain ditandai oleh warisan budaya tak benda yang disebut gula gending. Gula gending merupakan sebuah kotak untuk menjajakan harum manis yang memiliki beberapa sumber bunyi dan dimainkan untuk menarik perhatian calon pembeli (Gambar 1) Sebelum menjual harum manis, pedagang akan memainkan musik terlebih dahulu. Kondisi inilah yang menjadikan sebutan gula gending. Hal ini merupakan kreativitas dari pedagang dalam memasarkan barang dagangannya. Gula gending saat ini memiliki bentuk setengah lingkaran terbuat dari kaleng dengan enam kotak di salah satu sisi sebagai sumber bunyi yang biasa disebut sebagai tangka'.

Terdapat dua pendapat mengenai asalusul nama gula gending. Pendapat yang pertama berdasar teknik pukul dan barang yang dijual maka instrumen itu disebut gule gending (gule = gula, gending $=$ menabuh $)($ Anwar, 2010). Pendapat yang kedua lebih disebabkan karena alat ini untuk menjajakan semacam harum manis yang bahannya 
dari gula pasir maka musiknya disebut gula gending (DepDikBud, 1978/1979:34).

Instrumen ini pertama kali dibuat di Desa Kembang Kerang, Lombok Timur oleh almarhum Amaq Sakidep. Instrumen yang pertama kali dibuat sedikit berbeda dengan alat yang ada sekarang. Terjadi perkembangan pada jumlah kotak sumber suara yang pada mulanya berjumlah tiga buah kemudian menghilang sekitar tahun 1943 dan pada tahun 1945 muncul gula gending dengan kotak berjumlah enam buah.

A-D dan B-C adalah bagian tepi dari gula gending. A-D jaraknya $540 \mathrm{~mm}$ sedangkan B-C jaraknya $310 \mathrm{~mm}$. Kotak 1 sampai dengan 6 tingginya $138 \mathrm{~mm}$, tebal $47 \mathrm{~mm}$, lebar $65 \mathrm{~mm}$, dengan jarak antara masing-masing kotak $60 \mathrm{~mm}$.

E adalah lubang sebagai jalan untuk mengambil harum manis dengan garis tengah $120 \mathrm{~mm}$, sedangkan $\mathrm{F}$ merupakan tempat penyimpanan potongan kertas untuk pembungkus harum manis

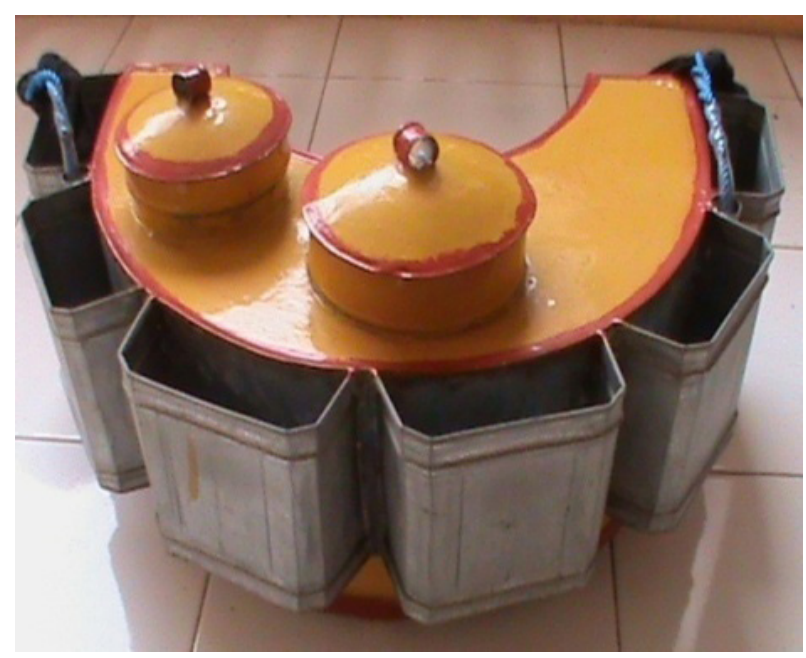

Gambar 1. Gula gending

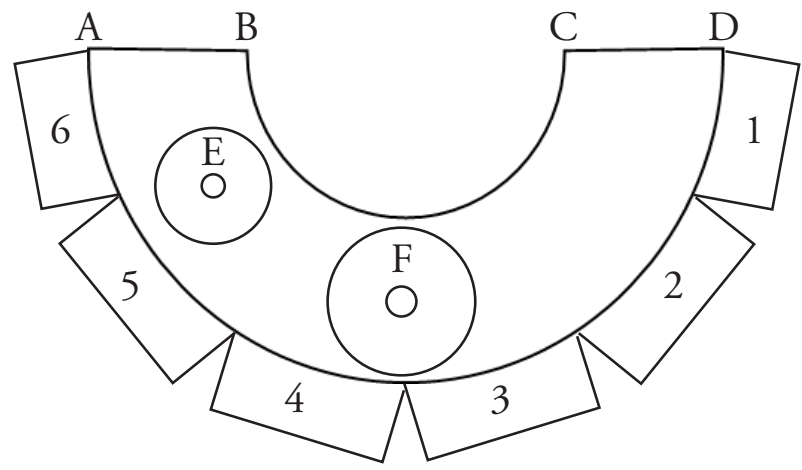

Gambar 2. Bagian-bagian gula gending (dilihat dari atas) (DepDikBud, 1978/1979:34) dengan garis tengah $150 \mathrm{~mm}$. Kotak yang berfungsi sebagai sumber nada adalah kotak 1 s.d. 5 , sedangkan kotak ke-6 berfungsi untuk menyimpan uang. Kotak-kotak dari 1 s.d. 6 semuanya tidak tertutup. Nada-nada do, re, mi pada kotak gula gending tidak berurutan: bisa saja nada do di urutan kedua atau nada mi di urutan kelima (Anwar, 2010).

Instrumen ini dimainkan dengan cara memukulkan 1 jari ke arah kotak kaleng dan jari yang dipukulkan bebas sesuai kemauan pemain (Wawancara, 13 Agustus 2010). Keseluruhan kotak kaleng ialah enam buah namun yang digunakan untuk menghasilkan nada berjumlah lima buah. Lagu-lagu yang dapat dimainkan oleh pedagang gula gending antara lain: Semarang (Sembarang), Bua Oda (Pinang Muda), Tempong Gunung (Menembus Gunung), Enyek Setoe (tekan sebelah), Turun Tangis (mulai menangis) dan Bao Daya (teduh pikiran). Nama lagu-lagu tersebut menunjukkan situasi atau lambang.

Pada saat lagu dimainkan orang-orang yang tertarik mendengar bunyi-bunyi yang berasal dari keterampilan pedagang dalam memainkan gula gending akan berkumpul dan tidak jarang kemudian membeli harum manis yang dijual. Dapat dikatakan bahwa dimainkannya lagu dalam gula gending adalah sebagai cara untuk melakukan promosi terhadap harum manis kepada masyarakat.

Dahulu dalam menjajakan harum manis dilakukan oleh dua orang, seorang membawa tangka' dan yang lain membawa rincik yaitu

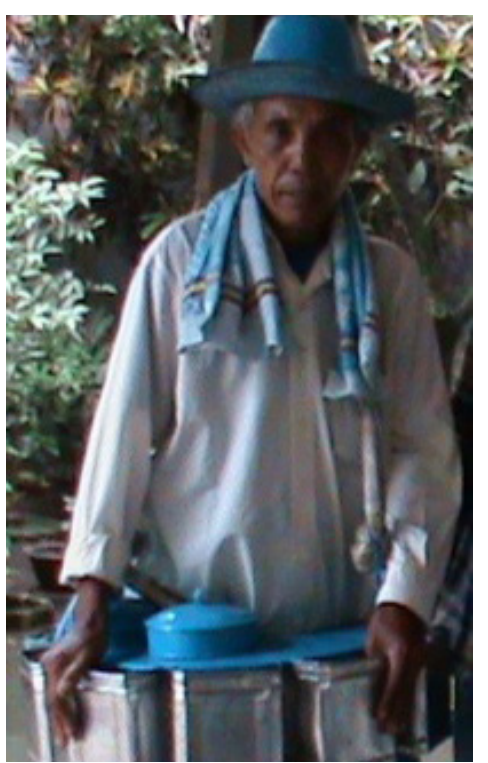

Gambar 3. Gula gending dalam berdagang 
sejenis alat perkusi dari lempengan logam yang berbentuk bundar (DepDikBud, 1978/1979:36). Lambat laun hal itu dianggap tidak praktis, rincik dihapuskan, diganti dengan penambahan jumlah kotak sumber suara.

Gula gending dahulu pernah ditanggap (dipanggil untuk memeriahkan upacara perkawinan) yaitu sewaktu acara nyongkolan berupa arak-arakan pengantin laki-laki dan perempuan dari rumah pengantin laki-laki ke rumah pengantin perempuan. Pada kesempatan tersebut tiga pemain gula gending bermain bersama-sama sambil berjalan mengarak pengantin. Pada masa sekarang hal seperti ini tidak pernah terjadi lagi (DepDikBud, 1978/1979:35).

Lagu yang dimainkan oleh pedagang biasanya lagu yang akrab di telinga masyarakat Sasak, misalnya lagu rakyat. Seiring dengan berjalannya waktu keberadaannya menjadi langka di masyarakat namun saat ini gula gending muncul kembali dengan fungsi yang berbeda, yaitu sebagai hiburan. Hal ini tampak menarik karena di tengah keberadaannya yang langka di masyarakat justru pertunjukkannya memiliki fungsi berbeda dari sebelumnya.

\section{Fakta Musikal}

Konsep ini menjelaskan bahwa terdapat sebuah fakta sonorik dari apa saja yang dikenali sebagai musik ketika membuat perbedaan antara musik dan bukan musik. Pengertian lebih lanjut menyebutkan bahwa sifat karakteristik musik akan dipertimbangkan di dalam konteks dari semua fenomena yang berhubungan dengan fakta musikal misalnya dari bahasa tubuh konduktor hingga ruang gedung konser. Terdapat rangkaian dari fenomena nonsonorik yang dianggap musikal oleh musisi dan disebutkan bahwa memisahkan musikal dari visual dan kinestetik merupakan hal yang sulit (Nattiez, 1990:41-44).

Pertunjukan gula gending dengan cara berdagang dilakukan secara tunggal. Biasanya pedagang menggunakan kaos atau kemeja yang dipadukan dengan celana panjang. Kepala pedagang itu sendiri menggunakan sebuah topi yang memiliki sisi melingkar atau topi dalam bentuk lain.

Gula gending diletakkan di bagian depan tubuh pedagang serta dibawa dengan menggendongnya menggunakan kain atau tali yang diikatkan di sisi instrumen. Gula gending dicat menggunakan warna yang cerah terutama di bagian tangka' yaitu tabung gula gending yang digunakan sebagai tempat harum manis, kecuali kotak-kotak kaleng yang berfungsi sebagai sumber bunyi.

Dalam dimensi sonorik, bunyi yang berasal dari kotak kaleng yang dipukul menggunakan jari-jari kedua tangan pedagang dimainkan secara bersahut-sahutan antara nada yang satu dan lainnya. Nada dalam gula gending setelah ditala akan diperoleh nada $\mathrm{f}^{1}, \mathrm{c \#}, \mathrm{g} \#^{1}, \mathrm{a}^{1}$, dan $\mathrm{d}^{1}$.

Pola ritme yang dimainkan oleh pedagang ialah monoton yaitu notasi $1 / 8$ dalam instrumen ini akan dimainkan dengan dua buah notasi 1/16 atau notasi $1 / 8$ bertitik yang akan dimainkan dengan tiga buah notasi $1 / 16$. Hal ini mempunyai arti jika ingin memainkan nada yang berbunyi lama maka harus memainkan nada pendek secara berulang-ulang.

Gambar 6 merupakan salah satu contoh karya yang dimainkan oleh gula gending secara tunggal. Dalam birama pertama, ketukan pertama tampak diawali oleh tanda istirahat dengan notasi $1 / 8$ bertitik diikuti oleh nada $a^{1}$ dalam notasi $1 / 16$. Ketukan kedua masih memainkan nada yang sama namun dengan nilai setengah ketuk lalu diikuti oleh nada $\mathrm{a}^{1}$ dan $\mathrm{c}^{1}$ dengan nilai masingmasing seperempat ketuk. Dalam ketukan ketiga terdapat empat buah notasi $1 / 16$ dengan nada pertama dan kedua ialah $\mathrm{a}^{1}$, lalu nada ketiga $\mathrm{c}^{1}$ kemudian kembali ke nada $a^{1}$. Ketukan keempat
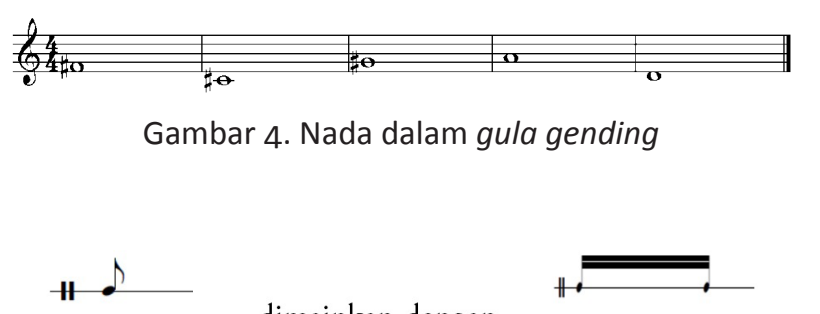

$$
\text { dimainkan dengan }
$$

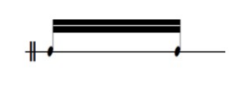

Not $1 / 8$

Not $1 / 16$

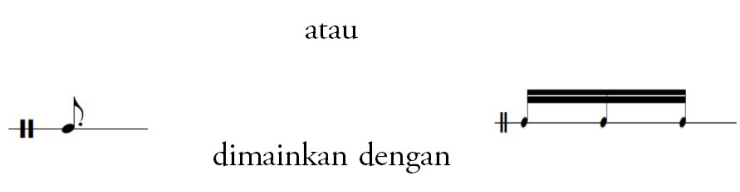

Not $1 / 8$ bertitik

Tiga buah not $1 / 16$ 
dalam birama pertama ditempati oleh dua buah notasi $1 / 4$ dengan nada $g \#^{1}$ dan $a^{1}$.

Birama kedua dimulai dengan empat buah notasi $1 / 16$ di mana nada pertama hingga ketiga ialah c\# $^{1}$ dan nada keempat g\# ${ }^{1}$. Ketukan kedua terdapat notasi $1 / 8$ dengan nada $\#^{1}$ diikuti dua buah notasi $1 / 16$ dengan nada $\mathrm{g}^{1}$ dan $\mathrm{f}^{1}$. Ketukan ketiga diawali dengan nada g $^{1}$ bernilai setengah ketuk dan dua buah nada $\mathrm{a}^{1}$ masing-masing bernilai seperempat ketuk. Pada ketukan keempat dipenuhi oleh empat buah notasi 1/16 dengan nada pertama dan kedua $\mathrm{c}^{1}$ kemudian nada ketiga serta keempat $\mathrm{d}^{1}$.

Birama berikutnya kemudian dilanjutkan dalam bentuk birama ketiga yang diawali oleh deretan nada $\mathrm{c}^{1}$ pada ketukan pertama dengan notasi 1/16, 1/8 dan 1/16. Pada ketukan kedua terdapat dua buah notasi $1 / 8$ dengan nada $a^{1}$ dan $\mathrm{g} \#^{1}$. Ketukan ketiga dipenuhi oleh empat buah notasi $1 / 16$ dengan nada $\mathrm{f}^{1}$ sebanyak tiga kali berturut-turut dan satu kali nada $\mathrm{a}^{1}$. Ketukan keempat juga ditempati oleh empat buah nada $1 / 16$ dengan nada $\mathrm{g}^{1}$ sebanyak dua kali dan nada $\mathrm{f \#}^{1}$ sebanyak dua kali.

Birama keempat ketukan pertama ditempati oleh empat buah notasi 1/16 dengan urutan nada dua buah nada $\mathrm{d}^{1}$ dilanjutkan nada $\mathrm{f}^{1}$ dan $\mathrm{g} \#^{1}$. Pada ketukan kedua terdapat dua buah notasi $1 / 8$ dengan nada $\mathrm{a}^{1}$ dan $\mathrm{g}^{1}$. Ketukan ketiga dipenuhi oleh empat buah notasi 1/16 dengan nada $\mathrm{f}^{1}$ sebanyak tiga kali diikuti oleh nada $\mathrm{a}^{1}$, lalu pada ketukan keempat dimainkan empat buah notasi 1/16 dengan nada pertama dan kedua ialah $\mathrm{g}^{1}$ serta nada ketiga dan keempat ialah $\mathrm{f}^{1}$.

Birama kelima ketukan pertama ditempati oleh empat buah notasi $1 / 16$ dengan nada $\mathrm{d}^{1}$

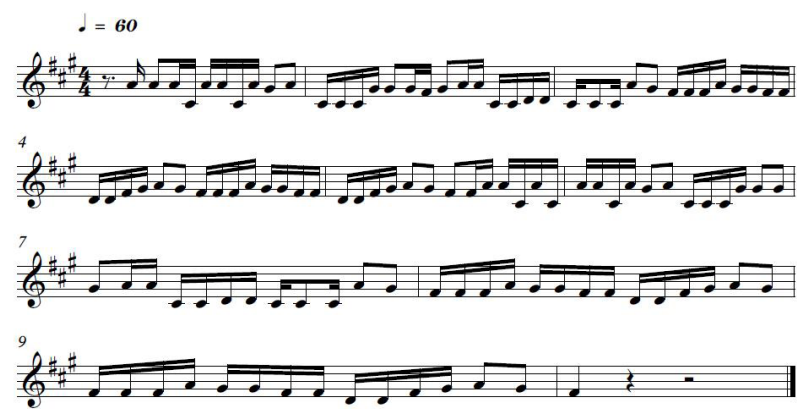

Gambar 6. Contoh karya yang dibawakan oleh gula gending secara tunggal sebanyak dua kali, setelah itu nada $\mathrm{f}^{1}$ dan $\mathrm{g} \#^{1}$. Pada ketukan kedua terdapat dua buah notasi 1/8 dengan nada $a^{1}$ dan g\# $^{1}$. Ketukan ketiga ditempati oleh notasi $1 / 8$ dengan nada $\mathrm{f}^{1}$ dilanjutkan oleh dua buah notasi $1 / 16$ dengan nada $\mathrm{f}^{1}$ dan $\mathrm{a}^{1}$. Pada ketukan keempat kembali ditempati oleh empat buah notasi $1 / 16$ namun dengan interval yang lebih jauh, yaitu dengan nada $a^{1}, c \#^{1}, a^{1}$ dan $c \#^{1}$.

Selanjutnya birama keenam di mana ketukan pertama ditempati oleh empat buah notasi 1/16 dengan nada a ${ }^{1}$ sebanyak dua kali lalu nada $\mathrm{c}^{1}$ dan kembali ke nada $a^{1}$. Pada ketukan kedua terdapat dua buan notasi $1 / 8$ dengan nada $\mathrm{g}^{1}$ dan $\mathrm{a}^{1}$, kemudian di ketukan ketiga muncul kembali empat buah nada 1/16 dengan nada c\# $^{1}$ sebanyak tiga kali dan diikuti oleh nada g $^{1}$. Ketukan terakhir pada birama enam berupa ketukan keempat yang ditempati oleh dua buah notasi 1/8 dengan nada $\mathrm{g}^{1}$ sebanyak dua kali.

Birama ketujuh terdiri dari empat ketukan di mana masing-masing ketukan memiliki motif yang berbeda-beda. Ketukan pertama terdapat satu buah notasi $1 / 8$ dengan nada $\#^{1}$ disertai dua buah notasi 1/16 dengan nada $a^{1}$ sebanyak dua kali. Ketukan kedua ditempati oleh empat buah notasi 1/16 dengan nada $\mathrm{c \#}^{1}$ sebanyak dua kali dan nada $\mathrm{d}^{1}$ sebanyak dua kali. Ketukan ketiga diisi oleh notasi $1 / 16$ dengan nada $\mathrm{c}^{1}$ lalu notasi $1 / 8$ dengan nada c\#1 kemudian kembali muncul notasi 1/16 dengan nada c\# $^{1}$. Ketukan keempat ditempati oleh dua buah notasi $1 / 8$ dengan nada $\mathrm{a}^{1}$ dan $\mathrm{g}^{1}$.

Birama kedelapan ketukan pertama diisi oleh empat buah notasi $1 / 16$ dengan nada $\mathrm{f}^{1}$ sebanyak tiga kali diikuti dengan nada $a^{1}$. Pada ketukan kedua terdapat empat buah notasi 1/16 dengan nada $\mathrm{g}^{1}$ sebanyak dua kali dan nada $\mathrm{f}^{1}$ sebanyak dua kali, di ketukan ketiga muncul kembali empat buah notasi $1 / 16$ dengan nada $\mathrm{d}^{1}$ sebanyak dua kali diikuti oleh nada $\mathrm{f}^{1}$ dan $\mathrm{g}^{1}$. Ketukan keempat ditempati oleh dua buah notasi $1 / 8$ dengan nada $\mathrm{a}^{1}$ dan $\mathrm{g} \#^{1}$.

Setelah birama kedelapan dilanjutkan dengan birama kesembilan di mana terdapat notasi dan nada-nada yang sama persis seperti pada birama kedelapan. Sebagai birama terakhir dari karya tersebut ialah birama kesepuluh yang ditempati oleh satu buah notasi, yaitu notasi $1 / 4$ dengan nada $\mathrm{f}^{1}$. 
Pada dimensi kinestetik maka instrumen ini dimainkan dengan memukulkan salah satu jari ke tengah kotak kaleng. Pedagang biasanya menggunakan jari tengah untuk memukul kotak, hal ini dilakukan tanpa disertai gerakan apa pun selain tangan yang berpindah-pindah dari kotak kaleng yang satu ke kotak lainnya.

Fakta musikal dalam pertunjukan gula gending sebagai sebuah hiburan yaitu melalui dimensi visual dapat dijelaskan bahwa sebagai sebuah hiburan pertunjukan dari instrumen ini ditampilkan dalam bentuk ensembel atau berkelompok. Pada saat ini semua pemain menggunakan seragam kemeja batik dipadukan dengan celana panjang. Pada saat pertunjukan dilakukan maka terdapat formasi pemain seperti berbaris terkadang juga berjajar.

Warna dari instrumen yang berbeda antara satu dengan lainnya terutama di bagian tangka' lebih disebabkan karena cat dengan warna-warna yang agak terang seperti hijau dan biru. Terdapat juga instrumen yang tidak dicat sehingga memiliki warna selayaknya kaleng. Kotak kaleng dari masingmasing instrumen terlihat tanpa cat dan tampak seperti tampilan kaleng pada umumnya.

Berdasarkan dimensi sonorik maka dapat dijelaskan bahwa bunyi yang dihasilkan lebih bervariasi karena berasal dari beberapa instrumen. Terdapat empat buah instrumen yang masing-masing memainkan bagian yang berbeda-beda yaitu dua instrumen memainkan bagian perkusi, satu instrumen memainkan motif melodi secara tetap dan satu instrumen memainkan melodi utama yang lebih cenderung terdengar seperti improvisasi.

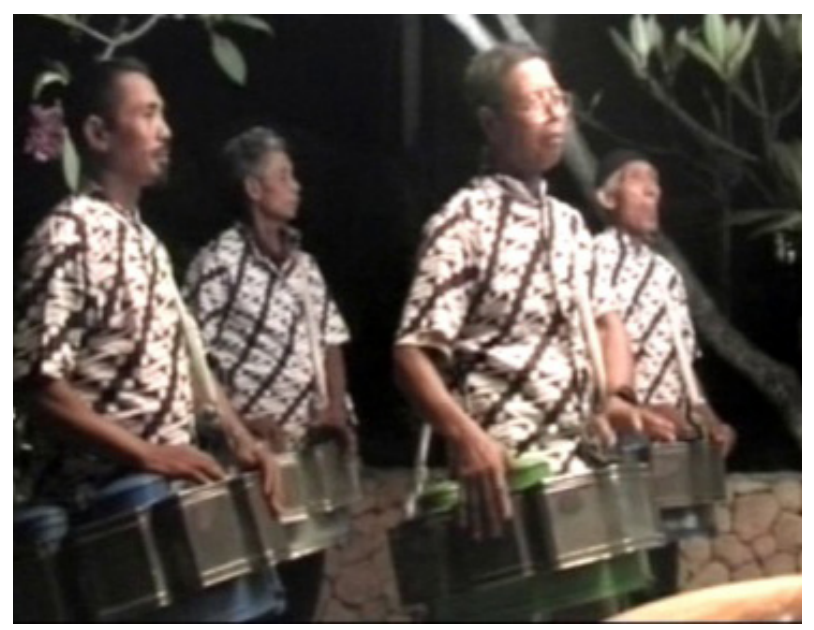

Gambar 7. Pertunjukan gula gending sebagai hiburan
Salah satu bagian perkusi dimainkan dengan memukul bagian atas dari tangka' gula gending menggunakan tangan kanan sedangkan satu instrumen lainnya dimainkan dengan memukulkan sejenis logam ke arah kotak kaleng. Satu instrumen kemudian dimainkan dengan memukul salah satu kotak kaleng secara tetap dan satu instrumen berikutnya memainkan melodi dengan memukul kotak kaleng secara bergantian.

Instrumen gula gending 1 pada birama pertama ketukan pertama yang ada pada gambar 8 terdapat tanda istirahat bernilai setengah ketuk dilanjutkan dua buah notasi 1/16 dengan nada c\#1 dan g\# $\#^{1}$. Ketukan kedua ditempati oleh notasi $1 / 16$ dengan nada $a^{1}$ diikuti tanda istirahat bernilai seperempat ketuk kemudian diikuti oleh dua buah notasi $1 / 16$ dengan nada $\#^{1}$ dan $a^{1}$. Ketukan ketiga diawali dengan tanda istirahat seperempat ketuk, dilanjutkan tiga buah notasi 1/16 dengan urutan nada $\mathrm{c}^{1}, \mathrm{~d}^{1}$ dan $\mathrm{c}^{1}$. Ketukan keempat dipenuhi oleh empat buah notasi seperempat dengan urutan nada $\mathrm{d}^{1}, \mathrm{c} \#^{1}, \mathrm{a}^{1}$ dan $\mathrm{c}^{1}$.

Ketukan pertama ditempati oleh empat buah notasi $1 / 16$ dengan nada yang sama yaitu $\mathrm{g} \#^{1}$, ketukan kedua diisi oleh empat buah notasi
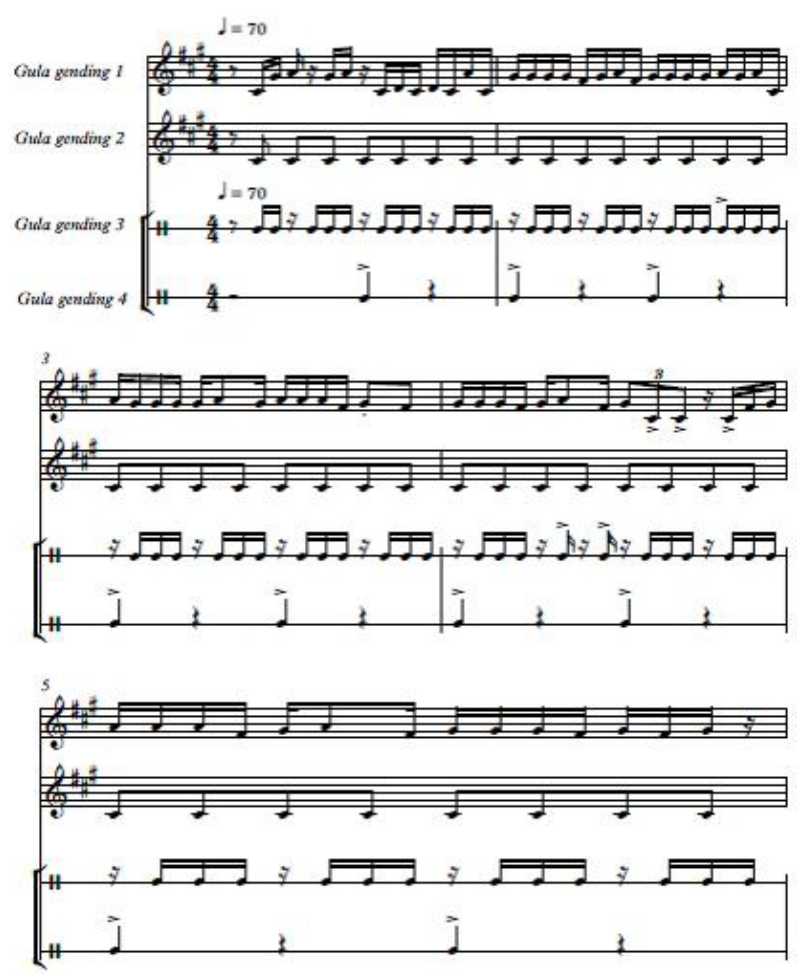

Gambar 8. Contoh karya yang dibawakan oleh gula gending secara berkelompok. 
1/16 dengan urutan nada $\mathrm{f}^{1}, \mathrm{~g} \#^{1}, \mathrm{a}^{1}$ dan $\mathrm{f} \#^{1}$. Pada ketukan ketiga terdapat pola sama seperti ketukan pertama, empat buah notasi 1/16 dengan nada yang sama, yaitu $\mathrm{g} \#^{1}$, lalu ketukan keempat diisi oleh empat buah notasi 1/16 dengan urutan nada $a^{1}$, g\# $^{1}, a^{1}$ dan $\mathrm{c \#}^{1}$.

Birama ketiga diawali oleh empat buah notasi $1 / 16$, di mana nada pertama ialah $a^{1}$ dan nada kedua hingga ke empat g\# $\#^{1}$. Pada ketukan kedua terdapat notasi $1 / 16$ dengan nada $\#^{1}$ dilanjutkan notasi $1 / 8$ dengan nada $\mathrm{a}^{1}$, lalu notasi $1 / 16$ dengan nada $\#^{1}$. Ketukan ketiga ditempati oleh empat buah notasi 1/16 dengan nada pertama hingga nada ketiga ialah $\mathrm{a}^{1}$ dan nada keempat $\mathrm{f}^{1}$. Sebagai akhir dari birama ketiga adalah ketukan ke empat di mana terdapat $\mathrm{g}^{1}$ dan $\mathrm{f \#}^{1}$.

Pada birama keempat ketukan pertama terdapat empat buah notasi $1 / 16$ di mana nada pertama hingga ketiga ialah $\#^{1}$ dan nada keempat f\#1 . Ketukan kedua diawali oleh notasi 1/16 dengan nada $\mathrm{g}^{1}$ diikuti notasi $1 / 8$ dengan nada $\mathrm{a}^{1}$, lalu notasi $1 / 16$ dengan nada $\mathrm{f}^{1}$. Pada ketukan ketiga terdapat triol dengan nada $\mathrm{g} \#^{1}$ dan dua nada $\mathrm{c} \#^{1}$ dengan aksentuasi. Ketukan keempat dimulai dengan tanda istirahat seperempat ketuk kemudian tiga buah notasi $1 / 16$ dengan urutan nada $\mathrm{c}^{1}$ dengan aksentuasi lalu $\mathrm{f}^{1}$ dan $\mathrm{g \#}^{1}$.

Birama kelima ketukan pertama dipenuhi oleh empat buah notasi 1/16 di mana nada pertama hingga ketiga ialah $\mathrm{a}^{1}$ dan nada keempat $\mathrm{f} \#^{1}$. Pada ketukan kedua terdapat notasi $1 / 16$ dengan nada g\# $\#^{1}$, dilanjutkan oleh notasi $1 / 8$ dengan nada a ${ }^{1}$ dan diikuti notasi $1 / 16$ dengan nada $\mathrm{f}^{1}$. Ketukan ketiga dipenuhi oleh empat buah notasi $1 / 16$ dengan nada pertama hingga ketiga ialah g $^{1}$ dan nada keempat $\mathrm{f \#}^{1}$. Sebagai akhir dari birama kelima ialah ketukan keempat yang ditempati oleh tiga buah notasi $1 / 16$ dengan urutan nada $\mathrm{g}^{1}, \mathrm{f} \#^{1}, \mathrm{~g} \#^{1}$ dan satu buah tanda istirahat seperempat ketuk.

Instrumen gula gending 2 memainkan pola ritme yang terdiri dari deretan notasi $1 / 8$ secara tetap dari birama pertama hingga birama kelima. Instrumen gula gending 3 memainkan pola ritme yang hampir sama sepanjang birama namun terdapat beberapa variasi. Pada birama pertama ketukan pertama muncul tanda istirahat bernilai setengah ketuk kemudian dilanjutkan dengan dua buah notasi $1 / 16$. Ketukan kedua diisi oleh tanda istirahat bernilai seperempat ketuk dilanjutkan tiga buah notasi $1 / 16$, pola ini terus muncul pada ketukan ketiga dan keempat hingga birama kedua ketukan pertama sampai ketukan ketiga.

Pada ketukan keempat terdapat empat buah notasi 1/16 dengan aksentuasi pada notasi pertama. Birama ketiga ketukan pertama hingga keempat dan birama keempat ketukan pertama ditempati oleh pola yang sama seperti yang ada di birama pertama ketukan kedua. Pada birama keempat ketukan kedua muncul tanda istirahat seperempat ketuk dilanjutkan notasi 1/16 dengan aksentuasi lalu muncul kembali tanda istirahat seperempat ketuk dan diikuti oleh notasi 1/16 dengan aksentuasi. Pada ketukan ketiga dan keempat muncul pola seperti pada birama pertama ketukan kedua.

Pada birama kelima ketukan pertama hingga ketukan keempat dipenuhi oleh pola tersebut. Instrumen gula gending 4 memainkan pola ritme yang lebih sederhana yaitu pada birama pertama ketukan pertama dan kedua terdapat tanda istirahat dua ketuk. Kemudian ketukan ketiga ditempati oleh notasi $1 / 4$ dengan aksentuasi kemudian diikuti oleh tanda istirahat bernilai satu ketuk pada ketukan keempat. Birama kedua dimulai oleh notasi $1 / 4$ dengan aksentuasi diikuti oleh tanda istirahat bernilai satu ketuk, lalu muncul kembali notasi $1 / 4$ dengan aksentuasi dan dilanjutkan tanda istirahat bernilai satu ketuk. Birama ketiga, keempat, dan kelima memainkan pola yang sama seperti terdapat pada birama kedua.

Dimensi kinestetik yang ada dalam penampilan gula gending sebagai hiburan mengandung gerakan tari di samping gerakan memainkan instrumen. Salah seorang pemain mengayunkan salah satu lengan ke arah atas dan lengan lainnya dilipat ke arah badan sembari menggerakkan pergelangan tangan. Gerakan ini dilakukan secara bergantian antara tangan kanan dan kiri yang diikuti ayunan badan dan kaki yang melangkah ke kanan dan ke kiri.

\section{Eksistensi Gula Gending}

Masyarakat Lombok sebagian besar pada awalnya memilih profesi sebagai petani dalam 
memenuhi kebutuhan hidupnya karena pada saat itu daerah ini memiliki budaya agraris. Masyarakat yang tidak memiliki sawah garapan akan mencari profesi lain yang salah satunya menjadi pedagang harum manis yang lebih dikenal dengan sebutan gula gending.

Dalam menjajakan harum manis, para pedagang menggendong tangka' berkeliling di perkampungan penduduk maupun pasar atau tempat keramaian lain. Sembari berjalan, para pedagang memainkan musik gula gending. Saat mendengar musik tersebut maka secara serta merta orang yang hendak membeli harum manis pun berdatangan. Seiring dengan perkembangan zaman banyak bermunculan jenis jajanan lain yang lebih menarik yang membuat masyarakat mulai meninggalkan jajanan tradisional termasuk harum manis tersebut.

Pada masa sekarang ini terdapat stereotipe dari masyarakat yang memojokkan pedagang gula gending, seperti jajanan tersebut kurang bersih serta mengandung bahan berbahaya bagi kesehatan terlebih lagi apabila dikonsumsi terlalu banyak dapat membuat batuk. Gula gending juga identik dengan konsumsi masyarakat kelas menengah ke bawah sehingga lambat laun keberadaan gula gending pun jarang dijumpai di Lombok.

Pada saat bidang pariwisata Pulau Lombok semakin gencar dipromosikan maka gula gending mulai dilirik kembali. Hal ini diikuti dengan perkembangan yang terjadi dalam pertunjukan musiknya. Gula gending kini menjadi hiburan untuk mendukung promosi pariwisata seiring dengan dinamika budaya yang terjadi di Lombok yaitu dari agraris menuju pariwisata.

Di dalam konsep musik dan dinamika budaya dikatakan bahwa tidak ada budaya yang lolos dari perubahan dari waktu ke waktu. Budaya merupakan hal yang stabil sehingga terus berlanjut dengan perubahan yang terjadi. Perubahan tersebut dapat terjadi pada masa lampau atau saat ini. Perubahan yang berasal dari dalam budaya tersebut disebut inovasi sedangkan yang berasal dari luar budaya disebut akulturasi.

Perubahan budaya memiliki empat buah proses yang terlebih dahulu dilakukan inovasi kemudian inovasi tersebut diterima secara sosial, lalu inovasi yang diterima secara sosial itu pun mengalami penyisihan hingga akhirnya menyatu dengan elemen budaya dan diterima sebagai bagian fungsi secara keseluruhan. Perubahan ini juga terjadi dalam musik namun yang ingin ditekankan di sini ialah mengenai penyebab dan akibat dari perubahan musik tersebut.

Disebutkan di sini bahwa perubahan internal dalam musik berasal dari konsep diadakannya musik tersebut di dalam budaya. Penelitian yang telah dilakukan terhadap proses dan alasan perubahan dalam musik akan diperoleh dua hal yaitu terjadi pada musisi yang pindah dari budaya tradisional menuju budaya urban dan musisi yang berada pada kondisi baru, apapun jenis organisasinya maka akan tercipta sosialitas dan musikalitas (Merriam, 1964:303-304, 318).

Berdasar sudut pandang tersebut maka dapat dijelaskan bahwa perkembangan pertunjukan musik gula gending pada masa lalu berupa penghapusan instrumen rincik yang menyertainya sehingga pelaku gula gending pada awalnya dua orang menjadi satu orang. Perubahan yang terjadi berupa penambahan kotak kaleng di bagian tangkaq' yaitu dari tiga buah menjadi enam buah kotak. Saat ini bentuk pertunjukan itu pun mengalami perkembangan menjadi sebuah pertunjukkan berkelompok dengan menggunakan empat buah instrumen gula gending.

Proses perubahan yang terjadi dalam pertunjukan tersebut dapat dilihat dari munculnya inovasi berupa penghapusan instrumen rincik dan penambahan kotak kaleng namun tampaknya inovasi ini mengalami penyisihan. Kemudian muncul inovasi berikutnya yaitu permainan secara berkelompok dengan menggunakan empat buah instrumen gula gending yang akhirnya diterima dalam budaya yang baru.

Konsep yang melandasi pertunjukan musik gula gending sebelum mengalami perkembangan berfungsi untuk mempromosikan barang dagangan berupa harum manis. Lagu yang dibawakan pada gula gending cenderung bebas serta tidak terikat oleh suatu aturan. Terdapat beberapa lagu yang diciptakan oleh para pelaku gula gending dan terkadang berupa improvisasi. Hal ini menandakan musik tersebut bisa menerima 
berbagai variasi sehingga lebih mudah untuk berubah.

Gula gending setelah memperoleh konsep yang baru menjadi hiburan untuk menunjang promosi pariwisata. Pertunjukan musik ini berkembang menjadi berbeda dari sebelumnya. Berdasar dimensi sonorik maka dapat dilihat pertunjukan musik gula gending dalam berdagang dimainkan secara tunggal dan terdiri dari satu suara yang membawakan melodi utama, kemudian berkembang menjadi sebuah hiburan yang menampilkan permainan secara berkelompok dengan pembagian suara menjadi empat suara, yaitu dua suara membawakan motif ritme, satu suara membawakan motif melodi, dan satu suara membawakan melodi utama.

Berdasar dimensi visual tampak penampilan pelaku gula gending dalam berdagang lebih sederhana daripada para pelaku pertunjukan musik ini sebagai sebuah hiburan. Berdasar dimensi kinestetik maka pelaku pertunjukan musik tersebut dalam berdagang tidak melakukan gerakan lain selain untuk menabuh instrumen. Para pelaku gula gending di dalam melakukan pertunjukan sebagai sebuah hiburan juga akan melakukan gerakan tarian.

Para pelaku pertunjukan musik tersebut mengalami perpindahan budaya dari agraris menuju pariwisata sehingga dalam budaya yang baru terciptalah fenomena sosial dan musikalitas yang baru. Terdapat suatu pergeseran lembaga dari lembaga tempat berlangsungnya pertunjukan musik yang semula di lembaga ekonomi seperti pasar dan tempat-tempat keramaian menuju lembaga pariwisata seperti hotel.

Status sosial yang dimiliki oleh para pelaku pertunjukan musik gula gending pun meningkat yaitu yang semula diidentikkan dengan masyarakat kelas menengah ke bawah kemudian bergaul dengan kalangan kelas atas seperti pengusaha pariwisata dan wisatawan. Kelompok gula gending juga mengalamai perubahan yaitu dari yang semula tergabung sebagai kelompok pedagang harum manis menjadi kelompok penyaji hiburan pariwisata.

\section{Simpulan}

Gula gending merupakan sebuah pertunjukan musik yang hidup di masyarakat Lombok sebagai perkembangan dari sarana promosi yang dilakukan pedagang harum manis. Musik ini dimainkan dengan cara menabuh instrumen gula gending yang menghasilkan lima nada. Pola ritme yang dimainkan monoton. Untuk menghasilkan agar nada berbunyi lama dilakukan dengan cara memainkan nada pendek secara berulang-ulang.

Keberadaan gula gending pernah menjadi langka di dalam masyarakat namun kini muncul kembali dan telah mengalami perkembangan. Berbagai inovasi telah dilakukan baik secara sonorik, visual, maupun kinestetik dari fungsinya sebagai sarana berdagang berkembang menjadi sebuah hiburan pariwisata. Hal ini terjadi karena perubahan budaya di Lombok yaitu dari agraris menuju pariwisata. Para pelaku gula gending dengan demikian juga ikut mengalami perubahan sehingga para pedagang memiliki lembaga, status sosial, kelompok dan musikalitas yang baru.

\section{Ucapan Terima Kasih}

Penulis menyampaikan terima kasih sebesarbesarnya kepada Bapak Lalu Satrun, Bapak I Komang Kantun, dan Bapak Fahmi sebagai nara sumber, serta Bapak Handayani yang telah berperan sebagai penterjemah pada saat wawancara di dalam penelitian.

\section{Kepustakaan}

Anwar, Khaerul. 2010. "Kadir Penyuluh Musik "Gule Gending" Lombok" dalam Kompas, Rabu 6 Oktober 2010.

Banoe, Pono. 2003. Kamus Musik. Yogyakarta: Penerbit Kanisius.

Departemen Pendidikan dan Kebudayaan Pusat Penelitian Sejarah dan Budaya, Proyek Penelitian dan Pencatatan Kebudayaan Daerah. 1978/1979. Ensiklopedi Musik dan Tari Daerah Nusa Tenggara Barat (LANJUTAN).

Marzoeki, Latifah Kodijat. 2004. Istilah-Istilah Musik. Jakarta: Penerbit Djambatan.

Merriam, Alan P. 1964. The Anthropology of Music. Illinois: University Press.

Nattiez, Jean-Jacques. 1990. Music and Discourse 
Toward a Semiology of Music. Translated by Carolyn Abbate. Princeton: Princeton University Press.

Prier, Karl-Edmund. 2009. Kamus Musik. Yogyakarta: Pusat Musik Liturgi.

Surakhmad, Winarno. 2004. Pengantar Penelitian Ilmiah Dasar, Metode dan Teknik. Bandung: Penerbit TARSITO.

Sukohardi, Al. 2009. Teori Musik Umum. Yogyakarta: Pusat Musik Liturgi.

Yunianto, Anang. 2009. Video dokumentasi acara PIGURA, Seniman Gula Gending, MDV/ PIG-05/NTB/09, durasi 27 menit, produser TVRI NTB.

\section{Informan}

Fahmi, pelaku gula gending, wawancara di Cakranegara, Mataram, Lombok Barat, NTB.

Handayani, penterjemah, wawancara tanggal 13 Agustus 2010 di Desa Kembang Kerang, Aik mel, Lombok Timur, NTB.

I Komang Kantun, tenaga teknis Taman Budaya NTB, wawancara tanggal 5 September 2010 melalui telepon selular.

Lalu Satrun, pelaku gula gending, wawancara tanggal 13 Agustus 2010 di Desa Kembang Kerang, Aik Mel, Lombok Timur, NTB. 